\title{
RM12 similar to substance $P$ from tachykinin of freshwater murrel Channa striatus influence intracellular ROS in vitro fish erythrocytes and developmental toxicity and antioxidant enzymes in vivo zebrafish embryo
}

\author{
Stefi V. Raju • Arnab Mukherjee • Purabi Sarkar • Praveen Kumar Issac • Christy Lite • \\ Bilal Ahmad Paray • Mohammad K. Al-Sadoon • Abdul Rahman Al-Mfarij · Jesu Arockiaraj
}

Received: 26 February 2021 / Accepted: 6 April 2021 / Published online: 21 May 2021

(C) The Author(s), under exclusive licence to Springer Nature B.V. 2021

\begin{abstract}
In this study, substance $\mathrm{P}$, an antioxidant peptide of tachykinin, was identified using bioinformatics tools from the earlier established muscle transcriptome of a freshwater murrel Channa striatus and the peptide was named RM12. The antioxidant properties of RM12 were screened using various colorimetric assays. The toxicity of RM12 was experimented using fish erythrocytes, and it is observed that the maximum concentration $(320 \mu \mathrm{M})$ of RM12 was found to have 15 or $20 \%$ of hemolytic activity; however, it was not significant with other tested concentrations $(10,20,40,80$, and $160 \mu \mathrm{M})$. Further, the in vivo antioxidant properties of RM12 were experimented on
\end{abstract}

S. V. Raju · P. Sarkar · P. K. Issac · J. Arockiaraj ( $\square)$ SRM Research Institute, SRM Institute of Science and Technology, Kattankulathur, 603203 Chennai, Tamil Nadu, India

e-mail: jesuaraj@hotmail.com

S. V. Raju · A. Mukherjee · P. Sarkar · J. Arockiaraj Department of Biotechnology, Faculty of Science and Humanities, SRM Institute of Science and Technology, Kattankulathur, 603203 Chennai, Tamil Nadu, India

C. Lite

Endocrine and Exposome Laboratory, Department of Zoology, Madras Christian College, Tambaram, Chennai 600 059, Tamil Nadu, India

B. A. Paray · M. K. Al-Sadoon · A. R. Al-Mfarij Department of Zoology, College of Science, King Saud University, PO Box 2455, Riyadh 11451, Saudi Arabia zebrafish embryo, the intracellular ROS level was estimated by $5 \mathrm{mM} \mathrm{H}_{2} \mathrm{O}_{2}$ stress in the zebrafish embryo, and inhibition of apoptosis was evaluated. The antioxidant enzymes were extracted from the $\mathrm{H}_{2} \mathrm{O}_{2}$-stressed zebrafish embryo, and the intracellular ROS was eliminated due to RM12. Collectively, the experiment showed that the substance $\mathrm{P}$ from the freshwater murrel C. striatus possessed potent antioxidant properties; thus, it can further be focused to develop it as antioxidant molecule in aquaculture organisms.

Keywords Substance P · Tachykinin - Channa striatus $\cdot$ Antioxidant mechanism · Intracellular ROS

$\begin{array}{ll}\text { Abbreviations } \\ \text { ROS } & \text { Reactive oxygen species } \\ \mathrm{H}_{2} \mathrm{O}_{2} & \text { Hydrogen peroxide } \\ \text { ESR } & \text { Electron spin resonance } \\ \text { DPPH } & \text { 2,2-Diphenyl-1-picryl-hydrazyl-hydrate } \\ \text { ABTS } & \text { 2,2-Azinobis 3-ethylbenzothiazoline- } \\ & \text { 6-sulfonic acid } \\ \text { SOAH } & \text { Superoxide anion radical scavenging } \\ & \text { assay } \\ \text { HORS } & \text { Hydroxyl radical scavenging assay } \\ \text { DCFH-DA } & \text { 2'-7'-Dichlorodihydrofluorescein } \\ & \text { diacetate } \\ \text { TEAC } & \text { Trolox equivalent antioxidant capacity } \\ \text { PMS } & \text { Phenazine methosulphate } \\ \text { NADH } & \text { Nicotinamide adenine dinucleotide } \\ \text { NBT } & \text { Nitro blue tetrazolium }\end{array}$




\section{Introduction}

The antioxidants are compounds that can delay or inhibit the oxidation process under the atmospheric oxygen or reactive oxygen species (ROS). They are involved in the defense mechanism of an organism against pathogens along with free radicals. Antioxidants have a major role in radicals and oxidative stress, cancer prophylaxis, therapy, and longevity. The intake of large amounts of flavonoids resulted in antioxidant, anti-inflammatory, and anti-proliferative activity on humans by preventing cancer and inflammatory diseases (Pisoschi and Negulescu 2012). The antioxidant peptide and their activity are dependent on the molecular mass, amino acid sequences, structure, and hydrophobicity (Sannasimuthu et al. 2019).

The ROS such as hydrogen peroxide $\left(\mathrm{H}_{2} \mathrm{O}_{2}\right)$, superoxide radical, and hydroxyl radical are the by-products of energy production and another metabolism. This ROS production is degrading the cellular components by disrupting the physiological balance in tissues. The higher concentrations of hydrogen peroxide present in freshwater can cause damage to the aquatic organisms. But still some organisms like spirulina can withstand oxidative stress; also they have an antioxidant mechanism to sustain and detoxify the free radicals and this results in the prevention of oxidative damages (Sannasimuthu et al. 2018). ROS is responsible for causing different disorders and diseases, which can be prevented or treated by antioxidant substances that ultimately improve the human health. The use of antioxidants in food, cosmetics, and pharmaceuticals has increased nowadays, and resulted in their multifaceted activities (Saeed et al. 2012). The occurrence of free radicals in food leads to rancidity, toxicity, and destruction of biomolecules. The presence of antioxidants from natural source inhibits the oxidation and formation of free radicals, thus preventing deterioration of food. The oxidative reaction of food leads to change in flavor, texture, aroma, and color. Cellular anti-oxidative enzymes such as superoxide dismutase, glutathione peroxidase, catalase, and some food-derived antioxidants protect tissues from these free radical-mediated oxidative stresses. To reduce the deterioration of food in food industry, synthetic antioxidants are being used with strict regulations (Mendis et al. 2005).

The free radicals formed cause many health disorders including both acute and chronic disorders such as aging, immunosuppression, inflammation, cancer, atherosclerosis, coronary heart disorder, neurodegeneration, diabetes mellitus, and Alzheimer's disease (Saeed et al. 2012). The free radicals and ROS were removed to maintain the prooxidantantioxidant balance, and it was used against various diseases (Sheih et al. 2009). Recently, many studies have been performed on herbal products that suggests the presence of antioxidants such as phenolics, flavonoids, tannins, and proanthocyanidins. For example, many medicinal plants are rich in antioxidants with free radical scavenging ability and some showed therapeutic usage for hepatic damages (Saeed et al. 2012).

The safety and toxicological testing of antioxidant components comprise of in vitro and in vivo model which is time consuming and expensive, requires a large number of animals, and is difficult to manage. Zebrafish (Danio rerio) is an emerging vertebrate model used for testing toxicity and drug discovery along with physiological, biological, and molecular alteration. The low-maintenance, high-fertility, ex-utero development and transparent eggs are the merits of zebrafish to use as experimental organism (Ismail et al. 2017). Since the zebrafish embryo develops externally and developmental changes can be observed, its usage in biological studies has been increased. As zebrafish is similar to embryogenesis in vertebrates including humans with 70-80\% homology (Carrillo et al. 2016), it is suitable for functional genomic and cell studies (Kang et al. 2013). The transgenic zebrafish with some gene alteration and targeted mutation are used for diseases like neurogenesis, cardiovascular, digestive system, immunology, cancer, inflammation, and diabetes (Ismail et al. 2017).

Oxidative stress is the imbalance of ROS and their antioxidant defense activity. Depending on the research, the antioxidant properties of natural products, chemical and biological methods were used to screen many antioxidant peptides (White et al. 2014). There are different methods used to measure antioxidant activity, using colorimetry or spectrophotometry and electron spin resonance (ESR). In colorimetry or spectrophotometry, the chromogen compound and antioxidant react and residual unoxidized chromogen compound is quantified. The ESR is analyzed based on the transition of unpaired electrons in the magnetic field. Recently, many bioactive peptides have been isolated with 2-20 amino 
acids long and exhibit a potent antioxidant activity. These peptides are affected by different parameters such as protein source, peptide structure and amino acid composition, molecular weight, and hydrolysis properties. It was reported that peptides with a molecular weight between 100 and $500 \mathrm{Da}$ and 1000 and $3500 \mathrm{Da}$ can be used for nutritional and pharmaceutical uses (Saidi et al. 2014). Some reports suggested that marine foods especially fishderived peptides exhibited greatest antioxidant activities (Sheih et al. 2009).

Among five tachykinin peptides identified in mammals, substance $\mathrm{P}$ is one of them. All these five tachykinin peptides are common in its carboxy terminal structure. Substance P is a neuropeptide which was synthesized in ribosome as a large amount of protein and converted to undecapeptide. This peptide is present in central and peripheral nervous system of vertebrates and plays a vital role (O'Connor et al. 2004). Substance P are mediated by tachykinin receptors especially neurokinin 1 (NK1) receptor for its biological activities (Harrison and Pierangelo 2001). A previous study Devane (2001) suggested the role of substance $\mathrm{P}$ during depression and anxiety, which led to the development of a new class of drugs as effective therapeutics against depression and anxiety. The biological activities such as antihypertensive, antagonistic, anticancer, and antioxidant of substance $\mathrm{P}$ were reported due to the presence of the amino acid sequence in the peptide: Arg -Pro-Lys-Gln-Gln -Phe-Phe-Gly-Leu-MetNH (Datar et al. 2004).

Hence, in our study, we are focusing on the antioxidant activity of the RM12, which has a similar amino acid sequence of an established substance $\mathrm{P}$ peptide as mentioned. RM12 peptide was identified from tachykinin using bioinformatics tools from an earlier established muscle transcriptome library of freshwater teleost Channa striatus. The physicochemical properties of the peptide, RM12, were evaluated using various online bioinformatics programs. Then, the peptide was screened in the molecular biology laboratory for antioxidant activity using DPPH (2,2-diphenyl-1-picryl-hydrazyl-hydrate) free radical scavenging assay, ABTS (2,2-azinobis (3-ethylbenzothiazoline-6-sulfonic acid) radical cation-based assay, superoxide anion radical scavenging assay (SOAH), and hydroxyl radical scavenging assay (HORS). Further the toxicity nature of RM12 was demonstrated by hemolytic assay using fish erythrocytes. Further, the toxicity and the antioxidant properties of RM12 were experimented on in vivo zebrafish model due to $5 \mathrm{mM} \mathrm{H}_{2} \mathrm{O}_{2}$ stress. The intracellular ROS elimination capability of RM12 was quantified in $\mathrm{H}_{2} \mathrm{O}_{2}$ stressed zebrafish by determining the antioxidant enzymes including lipid peroxidase, catalase, and superoxide dismutase. The ROS elimination was further observed under fluorescence microscope using DCFH-DA (2'-7'-dichlorodihydrofluorescein diacetate) stain.

\section{Materials and methods}

Identification, analysis, and synthesis of substance $\mathrm{P}$ (RM12)

A full-length tachykinin protein was identified from the earlier established muscle transcriptome of a freshwater teleost C. striatus (Raju et al. 2021). While analyzing the tachykinin protein using bioinformatics tools (antimicrobial prediction algorithm), a short peptide molecule named RM12 was identified, which is similar to peptide, substance P. The biological properties of the identified peptide, RM12, were analyzed using various bioinformatic programs including multiple sequence alignment and structural analysis. A helical wheel projection of RM12 was constructed and its hydrophobicity was calculated. The peptide has 12 amino acid residues, in which $\mathrm{R}$ and $\mathrm{M}$ represent the first and last letters of substance P peptide. Further, RM12 was synthesized at Zhengzhou Peptides Pharmaceutical Technology, China. The purity of the sequence was confirmed using HPLC and MALDI-TOF MS analysis, respectively. The obtained peptide was dissolved in endotoxin-free water and prepared a $1-\mathrm{mM}$ stock solution for further biological assays.

Evaluation of free radical scavenging potential of RM12

The antioxidant potential of RM12 peptide was screened using antioxidant assays such as DPPH radical scavenging activity assay, superoxide anion radical scavenging activity assay, hydroxyl radical scavenging activity assay, and Trolox equivalent antioxidant capacity assay. 
DPPH radical scavenging activity

DPPH was used to evaluate the free radical scavenging efficacy of the RM12 peptide by the calorimetric method (Sannasimuthu et al. 2019). In brief, 100 $\mu \mathrm{L}$ of RM12 peptide at different concentrations was combined with $100 \mu \mathrm{L}$ of $0.1 \mathrm{mM}$ DPPH solution in a 96-well plates and incubated in the dark at room temperature for $30 \mathrm{~min}$. The absorbance was recorded at $517 \mathrm{~nm}$. The free radical scavenging efficacy of RM12 peptide was evaluated through an equation:

DPPH free radical scavenging efficacy (\%)

$$
=[(\text { Acontrol }- \text { Apeptide }) / \text { Acontrol }] \times 100 \text {. }
$$

\section{Superoxide anion radical scavenging activity assay}

The superoxide anion radical scavenging activity of RM12 peptide was analyzed (Sannasimuthu et al. 2018). Superoxide anion radical was produced using $50 \mu \mathrm{l}$ of $(2.52 \mathrm{mM})$ nitrotetrazolium blue chloride followed by $50 \mu \mathrm{l}$ of $(624 \mathrm{mM}) \mathrm{NADH}$, and $50 \mu \mathrm{l}$ of different concentrations of RM12 peptide (10, 20, 40, and $80 \mu \mathrm{M})$. Using $50 \mu \mathrm{l}$ of $(120 \mu \mathrm{g} / \mathrm{ml})$ phenazine methosulfate solution, the reaction was initiated and incubated for $5 \mathrm{~min}$ in the dark at $25{ }^{\circ} \mathrm{C}$. The absorbance was determined at $560 \mathrm{~nm}$. The ability of scavenging superoxide anion radical is determined through an equation:

Superoxide anion radical scavenging activity (\%)

$=[($ Acontrol - Apeptide $) /$ Acontrol $] \times 100$.

\section{Hydroxyl radical scavenging activity assay}

The hydroxyl radical scavenging activity of RM12 peptide was analyzed (Sannasimuthu et al. $2019,2018)$ using a mixture of $30 \mu \mathrm{l}$ of $(5.0 \mathrm{mM})$ 1,10-phenanthroline, $30 \mu \mathrm{l}$ of $(15 \mathrm{mM})$ EDTA, and $30 \mu \mathrm{l}$ of $(5.0 \mathrm{mM}) \mathrm{FeSO} 4$ followed by $30 \mu \mathrm{l}$ of $(0.2 \mathrm{M})$ sodium phosphate buffer $(\mathrm{pH}=7.4)$. Further, $40 \mu \mathrm{l}$ of different concentrations of RM12 peptide $(10,20,40,80 \mu \mathrm{M})$ along with $40 \mu \mathrm{l}$ of $(0.03 \%) \mathrm{H}_{2} \mathrm{O}_{2}$ and then incubated for $60 \mathrm{~min}$ at $37{ }^{\circ} \mathrm{C}$. The absorbance was analyzed at $536 \mathrm{~nm}$.

Hydroxyl radical scavenging activity $(\%)$

$=[($ Acontrol - Apeptide $) /$ Acontrol $] \times 100$.
Trolox equivalent antioxidant capacity (TEAC) (or) ABTS assay

TEAC assay of RM12 peptide was performed (Sannasimuthu et al. 2018, 2019). ABTS radical cation $(\mathrm{ABTS} \bullet+)$ was produced by adding a $7-\mathrm{mM}$ ABTS stock solution with $2.45 \mathrm{mM}$ potassium persulfate. The samples were incubated in the dark for 12 or $16 \mathrm{~h}$ at room temperature, and the absorbance was noted as $0.70 \pm 0.02$ at $734 \mathrm{~nm}$ using 0.2 M PBS (pH 7.4) at $30{ }^{\circ} \mathrm{C}$. Experimental sample $(20 \mu \mathrm{l})$ or trolox at different concentrations was added to $180 \mu$ l of ABTS•- solution and was incubated for $6 \mathrm{~min}$ at $30{ }^{\circ} \mathrm{C}$ (Samaranayaka and Li-Chan 2011). The experiment was conducted in triplicate, and the absorbance was noted using a spectrophotometer. "Trolox equivalent antioxidant capacity" states the concentration of peptide giving a decrease of ABTS $\bullet+$ cation as that of $1 \mathrm{mM}$ of trolox.

$$
\begin{aligned}
& \text { ABTS radical scavenging activity }(\%) \\
& =[(\text { Acontrol }- \text { Asample }) / \text { Acontrol }] \times 100 \%
\end{aligned}
$$

Toxicity analysis of RM12

\section{Hemolytic assay using fish erythrocytes}

C. striatus blood ( $2 \mathrm{ml}$ ) was collected, centrifuged, and obtained erythrocyte pellets. The hemolytic assay was performed using the pellets along with different concentrations of RM12 peptide $(10 \mu \mathrm{M}$, $20 \mu \mathrm{M}, 40 \mu \mathrm{M}, 80 \mu \mathrm{M}, 160 \mu \mathrm{M}$, and $320 \mu \mathrm{M}$ ) (Guru et al. 2021). The erythrocytes were washed and rinsed thrice with $1 \mathrm{X}$ PBS. The samples were treated with RM12 peptide for $1 \mathrm{~h}$ at room temperature. After incubation, the samples were centrifuged and the supernatant were used to measure the reading at $540 \mathrm{~nm}$ (Le et al. 2015; Sarkar et al. 2020b, a). Triton $X$ and PBS were used as positive and negative controls respectively. The experiments were conducted in triplicate.

In vivo assays using the zebrafish embryo

\section{Zebrafish maintenance and feeding}

The zebrafish were maintained in a sterile condition to prevent infections caused by pathogenic 
microbes. They were maintained in plastic contains $(1 \times 1 \times 1 \mathrm{~m})$ with sufficient amount of water with some aquatic herbs such as Hydrilla to mimic their natural aquatic environment. The tank is kept along with a circulatory system that continuously aerates and filters the water to maintain the quality of the water that supports a healthy environment. The tanks are maintained at the temperature between 26 and $28{ }^{\circ} \mathrm{C}$. The water was thoroughly checked frequently and noted the water $\mathrm{pH}$ ranged between 6.5 and 7 . The animals were fed with brine shrimp at the satiation level three times a day as reported earlier (Blaser et al. 2010).

\section{Breeding and collection of zebrafish embryo}

The acclimatized fish were randomly selected for the breeding as explained earlier. The spawning was enabled to continue uninterruptedly for $30 \mathrm{~min}$ to $1 \mathrm{~h}$ and observed that ample embryos are noticeable at the bottom of the tank. The eggs were collected using suction pipette or strainer from the breeding tank without disturbing the breeders (one male and two females). After collecting the eggs, they were washed thrice with tap water and placed in E3 Medium that supports the growth and meets the metabolic demands of the early-stage embryo. Under a microscope, the eggs were observed; and through a needle or a pipette, fertilized eggs are isolated from unfertilized eggs (Otis and Farber 2016). The larvae are hatched until $72 \mathrm{~h}$ at the optimum temperature $\left(28^{\circ} \mathrm{C}\right)$. The collected embryos or the hatched larvae are used for further study.

\section{Cytotoxicity and morphological changes of zebrafish embryo}

The fertilized eggs (blastula stage) are selected and transferred to petri dishes containing an E3 embryo medium at around 2-6 h of post-fertilization. In $2 \mathrm{ml}$ of E3 medium, a fertilized egg in the blastula stage at $50 \%$ epiboly is placed. Randomly, 30 fertilized eggs were subjected to treatment with the peptide at different concentrations $(10,20,40$, and $80 \mu \mathrm{M})$. Every $24 \mathrm{~h}$, the embryos were observed taking into consideration of hatching, death, and physical abnormalities such as decreased or increased heart rate, altered axial curvatures (bent tail or bent spine), yolk sac edema, and hypopigmentation (Shaikh et al. 2016). The embryos were observed at $96 \mathrm{~h}$ and the average heart rate ratio was measured.

Biochemical analysis using zebrafish protein extract

\section{Lipid peroxidation assay}

The process in which the free radicals take electrons from the lipids in this process (usually occurs in cell membranes), resulting in cell damage called lipid peroxidation or degradation of lipids. Lipid peroxidation produces bi-products of reactive aldehydes such as malondialdehyde (MDA) and 4-hydroxynonenal (4-HNE). To measure the product produced after lipid peroxidation, thiobarbituric acid is used as a reagent. Thiobarbituric acid (TBA) $(0.5 \mathrm{~g})$ was dissolved in $20 \%$ trichloroacetic acid (TCA). The zebrafish lysate treated with RM12 peptide at different concentrations and reagents was added (1:2 ratio) in 96-well plates. The absorbance was recorded at $529 \mathrm{~nm}$ through a microplate reader.

\section{Superoxide dismutase assay}

Superoxide dismutase is the enzyme that acts as the therapeutic agent against the ROS. Nrf-2 gene regulates the antioxidant enzyme superoxide dismutase. Superoxide dismutase (SOD) is the major enzymes that represent the first line of protection against free radicals generated from oxygen and catalyze the elimination of superoxide free radicals (He et al. 2012). Four test samples of $0.8 \mathrm{ml}$ with $0.75 \mathrm{ml}$ of distilled water and to each sample $1.8 \mathrm{ml}$ of carbonate bicarbonate buffer were added. The blank was used to adjust zero. To control and test, $0.4 \mathrm{ml}$ of epinephrine was added and measured the optical density at $480 \mathrm{~nm}$ for $3 \mathrm{~min}$.

\section{Catalase assay}

Catalase is the enzyme that acts as the therapeutic agent against the ROS. Nrf-2 gene regulates the antioxidant enzyme catalase. Catalase is an essential enzyme for the dissociation of $\mathrm{H}_{2} \mathrm{O}_{2}$ into $\mathrm{O}_{2}$ and $\mathrm{H}_{2} \mathrm{O}$ (Hadwan 2018). A reaction mixture of $1 \mathrm{ml}$ phosphate buffer along with $0.1 \mathrm{ml}$ of sample and $0.5 \mathrm{ml}$ of hydrogen peroxide was made, and the 
reaction was inhibited by $0.2 \mathrm{ml}$ of dichromate acetic acid for 30-60 s. It was kept in a boiling water bath for $10 \mathrm{~min}$ and the color was developed; it was read at $620 \mathrm{~nm}$ using a microplate reader.

Staining assays using zebrafish larvae with DCFH-DA

DCFH-DA (2'-7'-dichlorodihydrofluorescein diacetate) staining is a commonly used method to evaluate the redox state of the cells. The redox state of the test samples was determined by detecting a rise in fluorescence (Du et al. 2017). Zebrafish larvae after exposure to $\mathrm{H}_{2} \mathrm{O}_{2}$ were treated with different concentrations of RM12 peptide (10, 20, 40, and $80 \mu \mathrm{M})$ every $24 \mathrm{~h}$ until $96 \mathrm{~h}$. DCFH-DA stock $(10 \mu \mathrm{L})$ was added to 3-4 larvae each of different concentration, and was incubated for $45 \mathrm{~min}$ in the dark at $37{ }^{\circ} \mathrm{C}$ and observed under a fluorescence microscope.

For the quantitative analysis, $100 \mu \mathrm{L}$ of the zebrafish lysate along with $10 \mu \mathrm{L}$ of DCFH-DA stock (10 $\mathrm{mg} / \mathrm{ml}$ in DMSO) incubated for 3-5 min in the dark at $37{ }^{\circ} \mathrm{C}$ and fluorescent intensity was measured in a microplate reader at $529 \mathrm{~nm}$.

\section{Statistical analysis}

The data were expressed as mean $(n=3) \pm$ standard deviation (SD). Further, the data were subjected to one-way ANOVA followed by Bonferroni post hoc method in Graph Pad Prism (ver. 5.0) at $p$ value 5 and 1.

\section{Results}

Bioinformatics analysis of RM12 peptide

RM12 peptide from tachykinin protein which is similar to substance $\mathrm{P}$ peptide sequence was identified from an earlier established teleost muscle transcriptome. The cDNA along with the amino acid residues of tachykinin, which consisted RM12, is provided in E. Suppl. Figure 1. The RM12 peptide has 12 amino acid sequence with 1479.97 Da molecular weight and a charge of +3 . The helical wheel projection suggests that the peptide is amphipathic. The secondary structure of tachykinin protein contains a random coil and alpha-helix, in which RM12 peptide is situated at the position random coil. Further, it was confirmed by constructing the 3D structure of tachykinin protein (E. Suppl. Figure 2) using I-Taser online server and viewed through pymol program. Antimicrobial prediction algorithm showed the presence of RM12 peptide in tachykinin protein. Considering the antioxidant qualities of RM12 from the bioinformatics analysis, the peptide was synthesized with the HPLC purity of $96.83 \%$; further, its sequence was confirmed by MALDI-TOF MS program.

Antioxidant activity of RM12

\section{DPPH radical scavenging activity}

DPPH was used to evaluate the antioxidant activity of RM12 peptide by producing free radicals. RM12 peptide showed a concentration-dependent antioxidant activity, in which the activity was compared with Trolox as a positive control. The lowest peptide concentration exhibited the lowest activity and the highest concentration exhibited the highest activity. The results showed that Trolox showed $92.45 \pm 2.09 \%$ at $60 \mu \mathrm{M}$ concentration and $57.41 \pm 1.26 \%$ at $10 \mu \mathrm{M}$ concentration, while RM12 showed $76.83 \pm 2.51 \%$ at $60 \mu \mathrm{M}$ concentration and $35.56 \pm 1.43 \%$ at $10 \mu \mathrm{M}$ concentration. The difference between the control and experiment was significant at $p<0.05$ (Table 1).

\section{Superoxide anion radical scavenging activity}

The RM12 peptide exhibited a dose-dependent radical scavenging activity. The results suggested that the antioxidant activity of RM12 peptide depends on its concentration used. Trolox was used as a positive control for comparison. The results showed the highest activity of Trolox and RM12 peptide in $60 \mu \mathrm{M}$ was $95.17 \pm 1.2 \%$ and $80.63 \pm 2.6 \%$, respectively, whereas the lowest activity of Trolox and RM12 peptide was noticed at $0 \mu \mathrm{M}$ concentration as $43.52 \pm 2.98 \%$ and $35.45 \pm 2.43 \%$, respectively, with a significance difference at $p<0.05$ (Table 1).

\section{Hydroxyl radical scavenging activity assay}

Hydroxyl radicals were used as a biologically active radical to screen the antioxidant activities. Both the 
Table 1 Radical scavenging activity of RM12 peptide from $C$. striatus Tachykinin observed from various antioxidant assays

\begin{tabular}{|c|c|c|c|c|c|c|c|c|}
\hline \multirow{2}{*}{$\begin{array}{l}\text { Conc. of RM12 } \\
(\mu \mathrm{M})\end{array}$} & \multicolumn{2}{|c|}{ DPPH activity (\%) } & \multicolumn{2}{|c|}{ SARS activity (\%) } & \multicolumn{2}{|c|}{ HRS activity (\%) } & \multicolumn{2}{|c|}{ ABTS activity (\%) } \\
\hline & RM12 & Trolox & RM12 & Trolox & RM12 & Trolox & RM12 & Trolox \\
\hline 10 & $\begin{array}{l}35.57^{* *} \\
\pm 0.43\end{array}$ & $\begin{array}{l}57.42 \\
\pm 1.26\end{array}$ & $\begin{array}{l}35.45 \\
\pm 1.43\end{array}$ & $\begin{array}{l}43.52 \\
\pm 2.98\end{array}$ & $\begin{array}{l}50.22^{*} \\
\pm 2.23\end{array}$ & $\begin{array}{l}61.65 \\
\pm 1.63\end{array}$ & $\begin{array}{l}46.09^{*} \\
\pm 0.71\end{array}$ & $\begin{array}{l}51.89 \\
\pm 1.88\end{array}$ \\
\hline 20 & $\begin{array}{l}38.66^{* *} \\
\pm 1.88\end{array}$ & $\begin{array}{l}65.55 \\
\pm 1.74\end{array}$ & $\begin{array}{l}44.23 \\
\pm 1.82^{*}\end{array}$ & $\begin{array}{l}54.91 \\
\pm 2.54\end{array}$ & $\begin{array}{l}56.48^{*} \\
\pm 1.88\end{array}$ & $\begin{array}{l}66.66 \\
\pm 1.77\end{array}$ & $\begin{array}{l}50.20^{*} \\
\pm 2.47\end{array}$ & $\begin{array}{l}56.46 \\
\pm 0.72\end{array}$ \\
\hline 30 & $\begin{array}{l}47.61^{* *} \\
\pm 1.06\end{array}$ & $\begin{array}{l}71.58 \\
\pm 1.19\end{array}$ & $\begin{array}{l}58.04 \\
\pm 1.21\end{array}$ & $\begin{array}{l}62.36 \\
\pm 1.09\end{array}$ & $\begin{array}{l}60.93^{*} \\
\pm 2.29\end{array}$ & $\begin{array}{l}70.91 \\
\pm 1.55\end{array}$ & $\begin{array}{l}56.64^{*} \\
\pm 2.96\end{array}$ & $\begin{array}{l}64.40 \\
\pm 0.88\end{array}$ \\
\hline 40 & $\begin{array}{l}55.25^{* *} \\
\pm 1.14\end{array}$ & $\begin{array}{l}77.24 \\
\pm 1.4\end{array}$ & $\begin{array}{l}64.06^{*} \\
\pm 2.11\end{array}$ & $\begin{array}{l}75.56 \\
\pm 2.84\end{array}$ & $\begin{array}{l}69.07^{*} \\
\pm 1.78\end{array}$ & $\begin{array}{l}77.84 \\
\pm 1.95\end{array}$ & $\begin{array}{l}64.87^{*} \\
\pm 2.85\end{array}$ & $\begin{array}{l}71.07 \\
\pm 1.42\end{array}$ \\
\hline 50 & $\begin{array}{l}63.49^{*} \\
\pm 1.29\end{array}$ & $\begin{array}{l}83.07 \\
\pm 1.78\end{array}$ & $\begin{array}{l}72.29^{*} \\
\pm 2.21\end{array}$ & $\begin{array}{l}86.34 \\
\pm 1.97\end{array}$ & $\begin{array}{l}70.69^{*} \\
\pm 2.33\end{array}$ & $\begin{array}{l}83.71 \\
\pm 1.57\end{array}$ & $\begin{array}{l}72.90 \\
\pm 1.37\end{array}$ & $\begin{array}{l}77.89 \\
\pm 2.17\end{array}$ \\
\hline 60 & $\begin{array}{l}76.83^{*} \\
\pm 1.5\end{array}$ & $\begin{array}{l}92.45 \\
\pm 1.06\end{array}$ & $\begin{array}{l}80.63^{*} \\
\pm 2.61\end{array}$ & $\begin{array}{l}95.17 \\
\pm 1.93\end{array}$ & $\begin{array}{l}76.81^{*} \\
\pm 1.65\end{array}$ & $\begin{array}{l}89.47 \\
\pm 2.09\end{array}$ & $\begin{array}{l}75.52^{*} \\
\pm 1.04\end{array}$ & $\begin{array}{l}84.26 \\
\pm 2.14\end{array}$ \\
\hline
\end{tabular}

Radical scavenging activity of RM12 peptide at different concentrations (10, 20, 30, 40, 50, and $60 \mu \mathrm{M})$ was assayed in 2,2-diphenyl1-picryly hydroxyl (DPPH) radical scavenging assay, superoxide anion radical scavenging (SARS) assay, hydroxyl radical scavenging assay and 2,2-azino-bis-3-ethylbenzothiazoline-6-sulfonic acid (ABTS) assay and compared with Trolox, as control. The single asterisk (*) and double asterisk (**) denote the significant difference between the control (Trolox) and treated samples (RM12) at $p<0.05$ and $p<0.001$, respectively, by one-way ANOVA followed by Bonferroni post hoc test using Graph Pad (ver. 5.0). The values are presented as mean \pm standard deviation $(n=3)$

positive control $(60 \mu \mathrm{M}$ as $89.47 \pm 3.09 \%)$ and the peptide $(76.81 \pm 1.65 \%)$ showed the highest activities at higher concentration. The activity percentage in the lowest concentration $(10 \mu \mathrm{M})$ of Trolox and RM12 peptide was $76.81 \pm 1.33 \%$ and $50.22 \pm 2.50 \%$, respectively. Thus, the activities depend on the concentration used as described in Table 1.

\section{Trolox equivalent antioxidant capacity (TEAC) (or) ABTS assay}

ABTS radical which is both lipid and water-soluble substance can be used to evaluate the antioxidant activity of RM12 peptide. The ABTS was considered hydrogen atom transfer action (HAT). The highest activity of Trolox, as well as RM12 peptide, was noticed at $60 \mu \mathrm{M}$ concentration as $84.26 \pm 2.37$ and $75.52 \pm 1.76 \%$, respectively. The lower concentration $(10 \mu \mathrm{M})$ of Trolox and RM12 peptide has $51.89 \pm 1.87 \%$ and $46.08 \pm 1.69 \%$, respectively, as presented in Table 1.

\section{Toxicity of RM12 on fish erythrocytes}

The toxicity was analyzed at different concentrations $(10,20,40,80,160$, and $320 \mu \mathrm{M})$ of RM12 peptide against fish erythrocytes. The result observed at maximum concentration of RM12 peptide was found to have $15-20 \%$ of hemolytic activity, which is very less comparing with positive control. Thus, the results

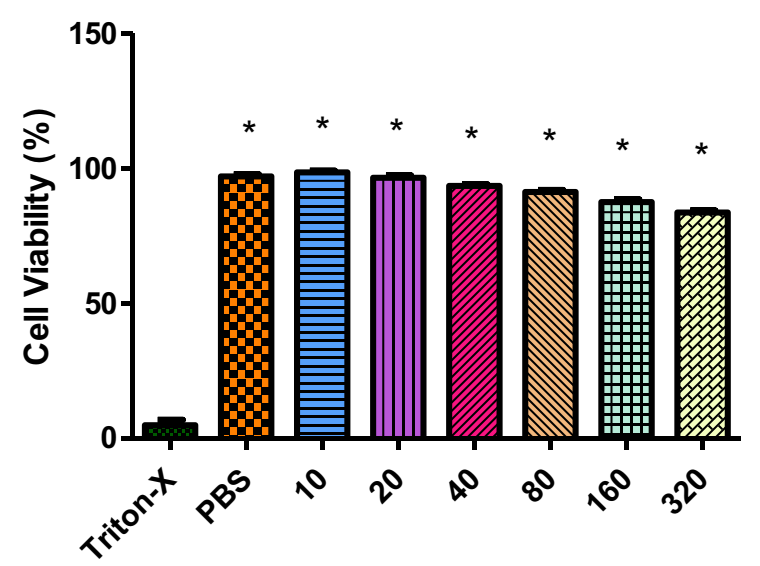

Concentration of RM12 peptide $(\mu \mathrm{M})$

Fig. 1 Hemolytic activity of RM12 at different concentrations $(10,20,40,80,160$, and $320 \mu \mathrm{M})$ against fish erythrocytes was assayed. The cell viability was decreasing with increase in concentration of peptide. The positive and negative controls used are Triton X100 and 1X PBS respectively. The graph is represented in percentage of cell viability. Values are shown as mean \pm standard deviation $(\mathrm{SD})(n=3)$. The asterisk $(*)$ represents the significant difference at $p<0.05$ by one-way ANOVA and Bonferroni post hoc test in Graph Pad (ver. 5.0) compared to the positive control 
were compared to positive control which showed high hemolytic activity while negative control showed less hemolytic activity (Fig. 1).

In vivo assays using zebrafish embryo

\section{Embryonic cytotoxicity and its morphological changes}

The zebrafish embryos were exposed to $5 \mathrm{mM}$ of $\mathrm{H}_{2} \mathrm{O}_{2}$ and observed every $24 \mathrm{~h}$ until $96 \mathrm{~h}$ postfertilization (hpf). At $24 \mathrm{hpf}$, embryos reached a late-embryo stage and some coagulated embryos were encountered in the positive control group. Few embryos were hatched in all experimental groups at the $48 \mathrm{hpf}$; at $72 \mathrm{hpf}$ all the embryos were hatched. Larvae in the positive control group were found to develop abnormalities like bent tail, deformed axial curvature, and yolk sac edema at the $96 \mathrm{hpf}$. The peptide-treated embryos were found to be normal and no abnormalities were observed. Hydrogen peroxide, a compound for inducing intracellular ROS, is responsible to acquire different health risks. The increased ROS level in the zebrafish embryos leads to apoptosis of cells, and henceforth, few early staged embryos were found to be coagulated and the hatched larvae developed abnormalities which ultimately lead to death. The RM12 peptide was found to possess an ability to eliminate the intracellular ROS level in the zebrafish embryo and inhibited apoptosis to occur. From the observations, the results are represented in E. Suppl. Figure 3. No cytotoxic effects and morphological changes were observed in the embryos treated with different concentrations of RM12 peptide.

Biochemical assay

\section{Lipid peroxidation assay}

Lipid peroxidation assay was determined to quantify the release of MDA (nmol/mg). TBA was used to perform the assay that reacts with the substance that was released after the degradation of lipids (occurring in the cell membrane). On heating, the lysate of the zebrafish embryo with TBA dissolved in TCA formed pink color adducts which were measured at $529 \mathrm{~nm}$. In the positive control group, on exposure to $\mathrm{H}_{2} \mathrm{O}_{2}$, the MDA release was higher. A significant $(p<0.001)$ decrease in the MDA release was encountered when compared to positive control as shown in Fig. 2 a.

\section{Superoxide dismutase assay}

The inhibition percentage by the superoxide dismutase enzyme released to eliminate the intracellular ROS. The enzyme was released by the action of RM12 peptide. SOD converted the superoxide free radical to oxygen to inhibit the intracellular ROS production. A $50 \%$ inhibition is equivalent to the release of 1 unit of SOD enzyme. A significant $(p<<0.001)$ increase in the inhibition was observed when compared to the control group as showed in Fig. 2b.

\section{Catalase assay}

The enzyme was released by the action of RM12 peptide for the dissociation of $\mathrm{H}_{2} \mathrm{O}_{2}$ into $\mathrm{O}_{2}$ and $\mathrm{H}_{2} \mathrm{O}$. The dose-dependent increase in the catalase activity was observed (Fig. 2c). The control group was found to possess the highest catalase activity to maintain the redox state of the cells.

\section{Staining assay using DCFH-DA}

The quantitative analysis of DCFH-DA was carried out to evaluate the intracellular ROS level in the zebrafish lysate, and the fluorescence was determined through a microplate reader at $529 \mathrm{~nm}$. A significant $(p<0.05)$ decrease in the fluorescence was observed compared to the positive control (Fig. 3a and b).

\section{Discussion}

Till now no reports have been obtained with regard to the antioxidant properties of substance P. Thus, this study deals with the antioxidant activity of RM12 peptide both in vivo and in vitro method. The peptide, RM12, which is similar to substance P, has a molecular weight of 1479.815 Da with net charge + 3 and amphipathic. The free radicle scavenging activity is high for the peptide which exhibits low molecular weight between 1000 and 3000 Da (Samaranayaka 
a
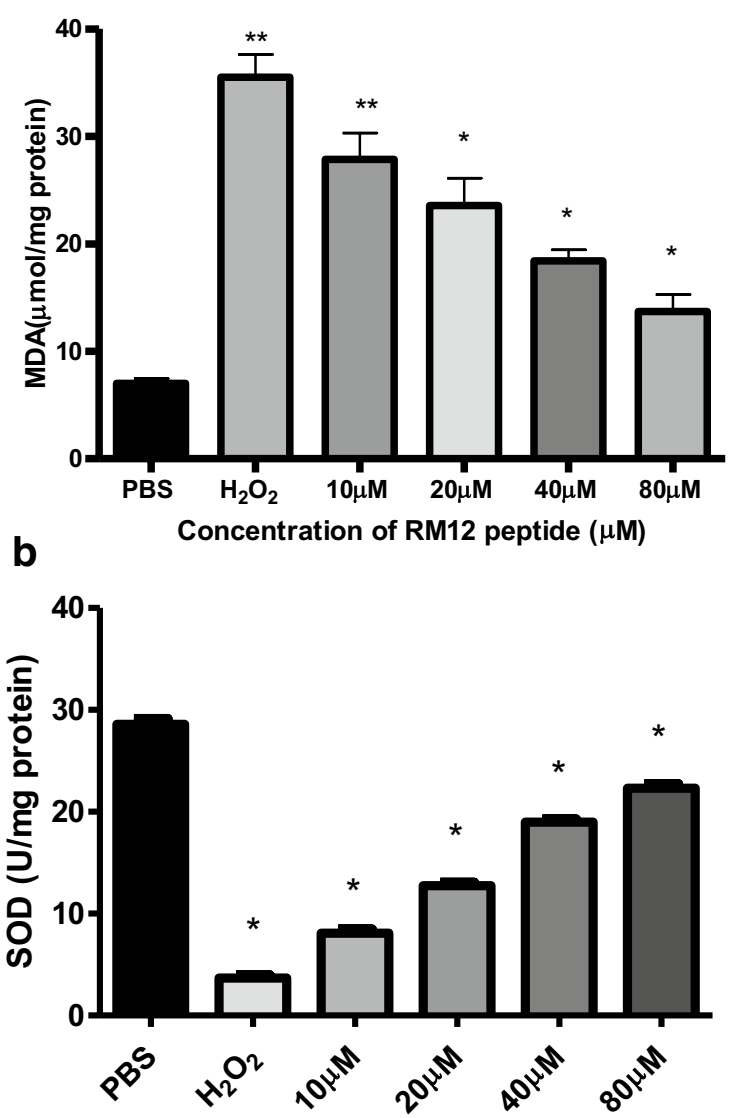

Concentration of RM12 peptide $(\mu \mathrm{M})$

C

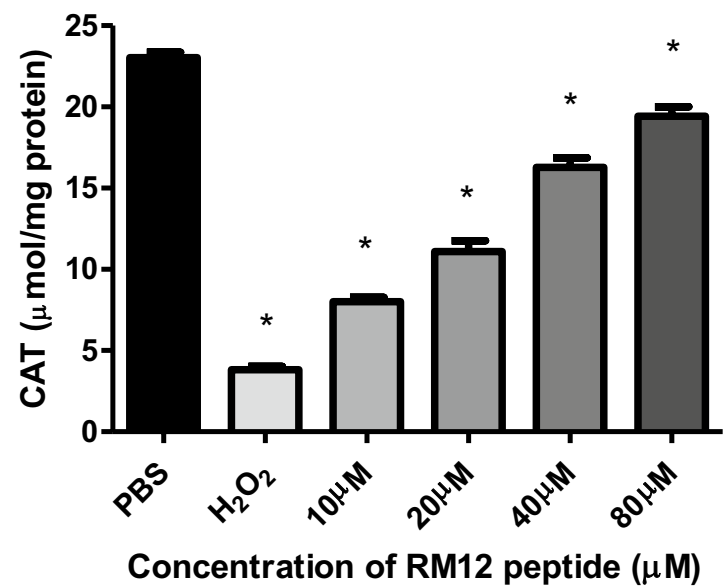

Fig. 2 Biochemical assays using zebrafish protein extract. a Lipid peroxidation level, b superoxide dismutase (SOD) activity, and c catalase (CAT) activity where hydrogen peroxide induced oxidative stress in zebrafish larvae. PBS and hydrogen peroxide were used as negative and positive controls, respectively. The data presented as mean of three independent experiments $(n=50 /$ group $) \pm \mathrm{SD}$. The asterisk (*) represents the significant difference at $p<0.05$ and Li-Chan 2011). The antioxidant property of each amino acid present in the peptide sequence determines the overall antioxidant property of the peptide. The type and number of amino acid side chains influence the antioxidant nature of peptides (Matsui et al. 2018). Also, the chemical and physical properties of amino acid sequence and the structure of the peptide determine the antioxidant characters of the peptide (Elias et al. 2008).

The scavenging property of any peptide depends on the position of amino acids in the sequence, hydrophobicity, and hydrogen bonding ability. It was reported that amino acids such as Cys, Met, Try, Trp, and Phe have the greatest antioxidant properties 1998). Moreover, Kawashima et al. (1979) stated that the amino acids such as Ala, Try, His, and Met at $\mathrm{N}$ terminal exhibit higher antioxidant activity. Some other findings suggested that both hydrophobic and aromatic amino acids help to increase the antioxidant properties of the peptide (Xiong et al. 2013). In accordance with these reports, RM12 consists of hydrophobic and aromatic amino acids including Ile (8\%), Leu (8\%), Phe (8\%), Met (8\%), Gly (8\%), and Pro (16\%); altogether, RM12 contributes antioxidant properties, thus scavenging free radicals (Guru et al. 2021).

The antioxidant activity assays of RM12 peptide exhibited radical scavenging property in a concentration-dependent manner. The colorimetric or spectrometric assays are commonly used to find out the antioxidant potential in which the liberation of radicals can be screened using these techniques. In DPPH assay, the antioxidant enzymes were found to inhibit the production of intracellular ROS by potential antioxidant RM12 peptide. In the experiment, the free radicals present in DPPH solution impart deep violet color at $520 \mathrm{~nm}$. The reaction with peptide leads to a change in color to deep yellow, which depends on antioxidant concentration and potency (Szabo et al. 2007). Results showed a concentration depended on antioxidant activity (Chi et al. 2015) which exhibits a significant increase along with an increase in concentration.

The superoxide anion radical reacts enzymatically or chemically to hydroxyl radicals resulting in oxidative stress (Tumbas et al. 2010). It is a major source of free radicals which is formed by lipid oxidation. The superoxide anion was converted to hydrogen peroxide for cell protection (Wang et al. 


\section{a}
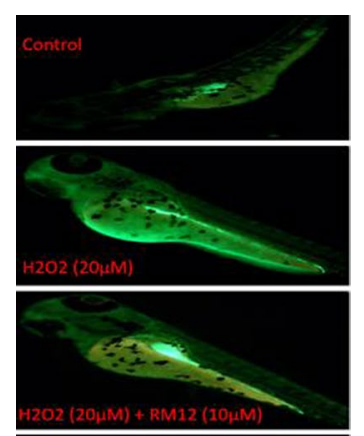

b
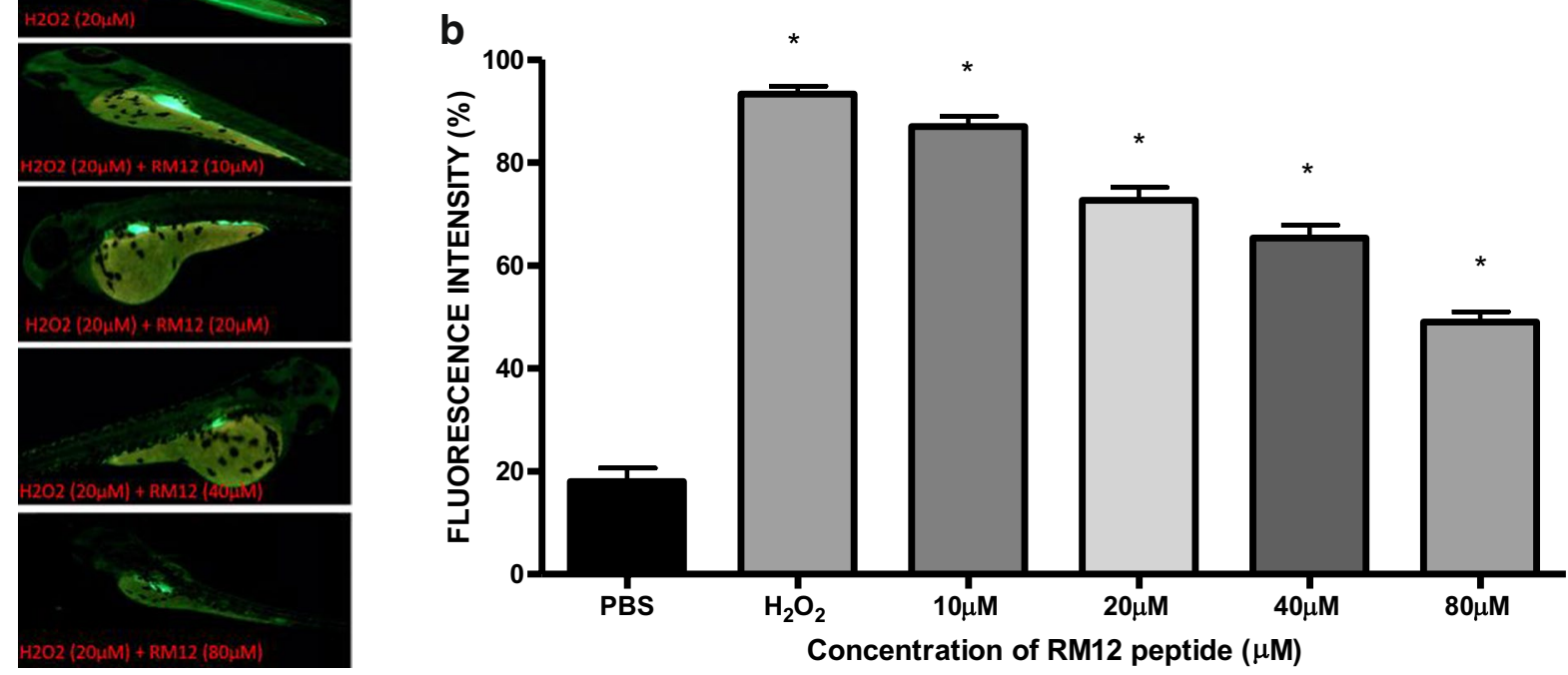

Fig. 3 ROS production in zebrafish larvae at different concentrations of RM12 using DCFDA dye in $96 \mathrm{~h}$. a DCFDA dye-stained fluorescent images of ROS production in zebrafish

larvae treated with different concentrations of RM12 at $96 \mathrm{~h}$. b Graphical representation of ROS production analyzed by image J

2013). To produce superoxide anion, two methods can be used, xanthine oxidase system and phenazine methosulphate (PMS) system in the presence of nicotinamide adenine dinucleotide (NADH). Superoxide anion reduces nitro blue tetrazolium (NBT) into formazan and can be read at $560 \mathrm{~nm}$ (Wang et al. 2013). Comparatively, RM12 peptide showed significant superoxide anion scavenging activity and it was found to be in a dose-dependent manner.

The hydroxyl radicals are reactive oxygen species that cause damage to biological molecules. The hydroxyl radicals are formed by reaction with DMSO, resulting in formaldehyde from which the hydroxyl radicals can be estimated (Pavithra and Vadivukkarasi 2015). In hydroxyl radical scavenging assay, the activity of RM12 peptide is strong and it reacts with biomolecules and helps to remove the hydroxyl radical in diseases (Xie et al. 2008). Proline was reported to have hydroxyl radical scavenging ability (Sarkar et al. 2020a, b). As RM12 peptide contains proline amino acid (16\%), RM12 peptide may exhibit a potent radical scavenging activity. The activity was increasing with an increase in the concentration of peptide used.

The formation ABTS radical cation can be estimated through spectrophotometric method to determine the antioxidant activity. ABTS and potassium persulfate react to form ABTS cation, a blue/green ABTS cation chromophore; the absorbance was read at $734 \mathrm{~nm}$. The ABTS radical cation is then converted to a colorless neutral form which can be expressed as TEAC. These assays are commonly used by researchers and in the food industry to estimate the antioxidant capacity of samples (Augusti Boligon et al. 2014). Amino acids such as His, Tyr, Met, and Cys exhibit antioxidant activity, especially histidine in which the imidazole ring gets decomposed (He et al. 2017). RM12 peptide contains His (8\%) which may have contributed radical scavenging ability to the peptide. The antioxidant activity has increased with 
the increase in concentration of peptide used, though the activity was not higher than Trolox, which is used as a positive control.

After preliminary in vitro antioxidant screening of peptide, in vivo assay using zebrafish as model organism was conducted. Zebrafish is an ideal organism for laboratory research as it is comparatively cheap, low maintenance, and commonly found and has homology with humans (Carrillo et al. 2016). The toxicity of RM12 was checked by exposing the peptide to zebrafish embryos and was analyzed for $96 \mathrm{~h}$. The malformation, heartbeat rate, and hatching rate were noted with different concentrations of RM12 and their respective control. In higher concentration $(80 \mu \mathrm{M})$ of RM12, no malformation was observed while the positive control has reported with malformation. Further, the zebrafish protein lysate was estimated using the Bradford test and biochemical assays or antioxidant enzymes were determined. After exposing zebrafish to hydrogen peroxide, the SOD and CAT get decreased. An increase in ROS inhibits antioxidant enzymes; thus, the use of RM12 peptide helps to increase antioxidant enzymes due to its radical scavenging ability. RM12 peptide can be used to reduce lipid peroxidation activity.

DCFH-DA is a rapid fluorescence assay used to determine ROS production. The acetate group of DCFH-DA was cleaved by the intracellular esterase and formed a cell membrane-impermeable product, $\mathrm{H}_{2} \mathrm{DCF}$, which undergo intracellular oxidation that leads to a higher yield of the fluorescent product DCF. RM12 peptide has shown significant activity to inhibit the production of fluorescent product DCF in larvae after exposure to ROS inducer, $\mathrm{H}_{2} \mathrm{O}_{2}$ (Guru et al. 2021). The quantitative analysis of DCFH-DA was carried out to evaluate the intracellular ROS level in the zebrafish embryo lysate, and the fluorescence was determined through a microplate reader at $529 \mathrm{~nm}$. It is suggested that the use of RM12 leads to a reduction in ROS level and intracellular oxidant stress in zebrafish.

The cytotoxicity of substance $\mathrm{P}$ was analyzed using different cell lines as well as different cells from peripheral blood ( $\mathrm{Fu}$ et al. 2011). It was reported that substance $\mathrm{P}$ enhances the cytotoxicity of human natural killer cells by producing cytotoxic-associated molecules and natural cytotoxicity receptors (Mashaghi et al. 2016). The major drawback mostly found in antimicrobial peptide is their toxicity; thus, the usage is limited. But comparatively, RM12 peptide showed a less toxicity towards fish erythrocytes even at higher concentrations. Thus, the RM12 peptide can be recommended for therapeutical uses in aquaculture.

\section{Conclusion}

RM12 peptide, which is similar to substance $P$, was screened for its biological activities using in silico analysis. Using the colorimetric methods, RM12 peptide was found to be a potent antioxidant material. Further analysis was performed using zebrafish as a vertebrate model organism. The toxicity of RM12 was performed in fish erythrocytes as well as zebrafish embryo and was observed as non-toxic. From exposing peptides with zebrafish, there was an increase in the antioxidant enzymes (SOD and CAT) while a decrease of lipid peroxidase. The zebrafish staining using DCFH-DA was found to represent the intracellular ROS production. Altogether, the study suggested that RM12 peptide was found to be an effective antioxidant drug with no cytotoxic properties.

Supplementary Information The online version contains supplementary material available at https://doi.org/10.1007/ s10695-021-00950-9.

Acknowledgement The authors would like to extend their sincere appreciation to the Deanship of Scientific Research at the King Saud University, Riyadh, Saudi Arabia for funding this Research Group Project No. RGP-289.

Author contribution Conceived, designed the experiments, and wrote the article: Stefi V. Raju, Arnab Mukherjee, Purabi Sarkar, Praveen Kumar Issac, Christy Lite, and Jesu Arockiaraj; performed the experiments: Stefi V. Raju and Arnab Mukherjee; analyzed the data and wrote the article: all the authors; contributed reagents/materials/analysis tools and wrote the article: Christy Lite, Bilal Ahmad Paray, Mohammad K. Al-Sadoon, Abdul Rahman Al-Mfarij, Jesu Arockiaraj; supervised the research: Jesu Arockiaraj; all authors read and approved the final manuscript.

Funding This study was supported by the Research Group Project (No. RGP-289) funded by Deanship of Scientific Research, King Saud University, Riyadh, Saudi Arabia. 
Data availability The required data have been provided in the article as figures in the main article as well as in the E-supplement document.

\section{Code availability Not applicable.}

\section{Declarations}

Ethics approval and consent to participate This research does not involve any human objects; however, we have performed assays using zebra fishes. The fishes were collected, handled, experimented, and sampled as per the Institute animal ethical handling procedure and guidelines. All authors are aware of the details of their research work that are presented in the current manuscript and gave their consent to publication.

Conflict of interest The authors declare no competing interests.

\section{References}

AugustiBoligon A, Mansur Machado M, LindeAthayde M (2014) Technical evaluation of antioxidant activity. Tech Eval Antioxid Act Med Chem 4:517-522. https://doi.org/ 10.4172/2161-0444.1000188

Blaser RE, Chadwick L, McGinnis GC (2010) Behavioral measures of anxiety in zebrafish (Danio rerio). Behav Brain Res 208:56-62. https://doi.org/10.1016/j.bbr.2009.11.009

Carrillo W, Gómez-Ruiz JA, Miralles B et al (2016) Identification of antioxidant peptides of hen egg-white lysozyme and evaluation of inhibition of lipid peroxidation and cytotoxicity in the Zebrafish model. Eur Food Res Technol 242:1777-1785. https://doi.org/10.1007/s00217-016-2677-1

Chen HM, Muramoto K, Yamauchi F et al (1998) Antioxidative properties of histidine-containing peptides designed from peptide fragments found in the digests of a soybean protein. J Agric Food Chem 46:49-53. https://doi.org/10. 1021/jf970649w

Chi C, Wang B, Hu F et al (2015) Purification and identification of three novel antioxidant peptides from protein hydrolysate of bluefin leatherjacket (Navodon septentrionalis) skin. Food Res Intl 73:124-129. https://doi.org/10. 1016/j.foodres.2014.08.038

Datar P, Srivastava S, Coutinho E et al (2004) Substance P: structure, function, and therapeutics. Curr Top Med Chem 4:75-103. https://doi.org/10.2174/1568026043451636

Devane CL (2001) Substance P: a new era, a new role. Pharmacotherapy 21:1061-1069

Du J, Cai J, Wang S et al (2017) Oxidative stress and apotosis to zebrafish (Danio rerio) embryos exposed to perfluorooctane sulfonate (PFOS) and $\mathrm{ZnO}$ nanoparticles. Int $\mathrm{J}$ Occup Med Environ Health 30:213-229. https://doi.org/ 10.13075/ijomeh.1896.00669

Elias RJ, Kellerby SS, Decker EA (2008) Antioxidant activity of proteins and peptides. Crit Rev Food SciNutr 48:430441. https://doi.org/10.1080/10408390701425615
Fu WX, Qin B, Zhou AP et al (2011) Regulation of NK92MI cell cytotoxicity by substance P. Wiley Online Libr 74:107-113. https://doi.org/10.1111/j.1365-3083.2011. 02550.x

Guru A, Lite C, Freddy AJ, et al (2021) Intracellular ROS scavenging and antioxidant regulation of WL15 from cysteine and glycine-rich protein 2 demonstrated in zebrafish in vivo model. Dev Comp Immunol 114: https://doi.org/ 10.1016/j.dci.2020.103863

Hadwan MH (2018) Simple spectrophotometric assay for measuring catalase activity in biological tissues. BMC Biochem 19: https://doi.org/10.1186/s12858-018-0097-5

Harrison S, Pierangelo G (2001) Substance P. Intl J Biochem Cell Biol 33:555-576. https://doi.org/10.1016/s13572725(01)00031-0

He R, Ju X, Yuan J et al (2012) Antioxidant activities of rapeseed peptides produced by solid state fermentation. Food Res Intl 49:432-438. https://doi.org/10.1016/j.foodres. 2012.08.023

He L, He T, Farrar S et al (2017) Antioxidants maintain cellular redox homeostasis by elimination of reactive oxygen species. Cell Physiol Biochem 44:532-553. https://doi. org $/ 10.1159 / 000485089$

Ismail H, Hashim Z, Soon W et al (2017) Comparative study of herbal plants on the phenolic and flavonoid content, antioxidant activities and toxicity on cells and zebrafish embryo. J Trad Complementary Med 7:452-465. https:// doi.org/10.1016/j.jtcme.2016.12.006

Kang MC, Cha SH, Wijesinghe WAJP et al (2013) Protective effect of marine algae phlorotannins against AAPHinduced oxidative stress in zebrafish embryo. Food Chem 138:950-955. https://doi.org/10.1016/j.foodchem.2012. 11.005

Kawashima K, Itoh H, Miyoshi M, Chibata I (1979) Antioxidant properties of branched-chain amino acid derivatives. Chem Pharm Bull 27:1912-1916. https://doi.org/10.1248/ cpb.27.1912

Le CF, Yusof MYM, Hassan H et al (2015) In vitro properties of designed antimicrobial peptides that exhibit potent antipneumococcal activity and produces synergism in combination with penicillin. Sci Rep 18:9761. https://doi. org/10.1038/srep09761

Mashaghi A, Marmalidou A, Tehrani M et al (2016) Neuropeptide substance $\mathrm{P}$ and the immune response. Cell Mol Life Sci 73:4249-4264. https://doi.org/10.1007/ s00018-016-2293-z

Matsui R, Honda R, Kanome M et al (2018) Designing antioxidant peptides based on the antioxidant properties of the amino acid side-chains. Food Chem 245:750-755. https:// doi.org/10.1016/j.foodchem.2017.11.119

Mendis E, Rajapakse N, Kim SK (2005) Antioxidant properties of a radical-scavenging peptide purified from enzymatically prepared fish skin gelatin hydrolysate. J Agri Food Chem 53:581-587. https://doi.org/10.1021/jf048877v

O'Connor TM, O'Connell J, O'Brien DI et al (2004) The role of substance $\mathrm{P}$ in inflammatory disease. J Cell Physiol 201:167-180. https://doi.org/10.1002/jcp.20061

Otis JP, Farber SA (2016) High-fat feeding paradigm for larval zebrafish: feeding, live imaging, and quantification of food intake. J Vis Expt 116:54735. https://doi.org/10.3791/ 54735 
Pavithra K, Vadivukkarasi S (2015) Evaluation of free radical scavenging activity of various extracts of leaves from Kedrostisfoetidissima (Jacq.). Cogn Food Sci Hum Wellness 4:42-46. https://doi.org/10.1016/j.fshw.2015.02.001

Pisoschi AM, Negulescu GP (2012) Methods for total antioxidant activity determination: a review. Biochem Anal Biochem 01:1-10. https://doi.org/10.4172/2161-1009.10001 06

Raju S V., Sarkar P, Pasupuleti M, et al (2021) Pharmacological importance of TG12 from tachykinin and its toxicological behavior against multidrug-resistant bacteria Klebsiella pneumonia. Comp Biochem Physiol Part C Toxicol Pharmacol 108974. https://doi.org/10.1016/j.cbpc.2021. 108974

Saeed N, Khan MR, Shabbir M (2012) Antioxidant activity, total phenolic and total flavonoid contents of whole plant extracts Torilis leptophylla L. BMC Complement Altern Med 12: https://doi.org/10.1186/1472-6882-12-221

Saidi S, Deratani A, Belleville M-P et al (2014) Antioxidant properties of peptide fractions from tuna dark muscle protein by-product hydrolysate produced by membrane fractionation process. Food Res Intl 65:329-336. https://doi. org/10.1016/j.foodres.2014.09.023

Samaranayaka AGP, Li-Chan ECY (2011) Food-derived peptidic antioxidants: a review of their production, assessment, and potential applications. J Fun Food 3:229-254. https://doi.org/10.1016/j.jff.2011.05.006

Sannasimuthu A, Kumaresan V, Anilkumar S et al (2019) Design and characterization of a novel Arthrospiraplatensis glutathione oxido-reductase-derived antioxidant peptide GM15 and its potent anti-cancer activity via caspase-9 mediated apoptosis in oral cancer cells. Free Radic Biol Med 135:198-209. https://doi.org/10.1016/j.freer adbiomed.2019.03.006

Sannasimuthu A, Kumaresan V, Pasupuleti M et al (2018) Radical scavenging property of a novel peptide derived from C-terminal SOD domain of superoxide dismutase enzyme in Arthrospiraplatensis. Algal Res 35:519-529. https:// doi.org/10.1016/j.algal.2018.09.028

Sarkar P, Lite C, Kumar P, et al (2020a) TL15 of Arthrospira platensis sulfite reductase scavenges free radicals demonstrated in oxidant induced larval zebrafish (Danio rerio) model. Int J Biol Macromol. https://doi.org/10.1016/j.ijbio mac.2020.10.222
Sarkar P, Stefi RV, Pasupuleti M et al (2020b) Antioxidant molecular mechanism of adenosylhomocysteinase from cyanobacteria and its wound healing process in fibroblast cells. Mol Biol Rep 47:1821-1834. https://doi.org/10. 1007/s11033-020-05276-y

Shaikh RU, Pund MM, Gacche RN (2016) Evaluation of antiinflammatory activity of selected medicinal plants used in Indian traditional medication system in vitro as well as in vivo. J Tradit Complement Med 6:355-361. https://doi. org/10.1016/j.jtcme.2015.07.001

Sheih I-C, Wu T-K, Fang TJ (2009) Antioxidant properties of a new antioxidative peptide from algae protein waste hydrolysate in different oxidation systems. Elsevier. https://doi. org/10.1016/j.biortech.2009.02.014

Szabo MR, Idiţoiu C, Idiţoiu I et al (2007) Improved DPPH determination for antioxidant activity spectrophotometric assay. Springer 61:214-216. https://doi.org/10.2478/ s11696-007-0022-7

Tumbas V, Jasna ${ }^{2}$ J, Jasnačanadanovi'c-Brunet J, et al (2010) Superoxide anion radical scavenging activity of bilberry (Vaccinium myrtillus L.). J Berry Res 1:13-23. https:// doi.org/10.3233/BR-2010-002

Wang B, Wang Y-M, Chi C-F et al (2013) marine drugs Isolation and characterization of collagen and antioxidant collagen peptides from scales of croceine croaker (Pseudosciaenacrocea). Mar Drugs 11:4641-4661. https://doi.org/10. 3390/md11114641

White PAS, Oliveira RCM, Oliveira AP et al (2014) Antioxidant activity and mechanisms of action of natural compounds isolated from lichens: a systematic review. Molecules 19:14496-14527. https://doi.org/10.3390/molec ules 190914496

Xie Z, Huang J, Xu X, Jin Z (2008) Antioxidant activity of peptides isolated from alfalfa leaf protein hydrolysate. Food Chem 111:370-376. https://doi.org/10.1016/j.foodc hem.2008.03.078

Xiong S, Yao X, Li A (2013) Antioxidant properties of peptide from cowpea seed. Int J Food Prop 16:1245-1256. https:// doi.org/10.1080/10942912.2011.582976

Publisher's note Springer Nature remains neutral with regard to jurisdictional claims in published maps and institutional affiliations. 